\title{
MOODS OF BITTERNESS \\ How Political Polarisation has Influenced \\ Zimbabwean Elections
}

\author{
By \\ Norman Mlambo PhD
}

Dr Mlambo is a Researcher and Head of the Peace and Security Research Unit at the Africa Institute of South Africa

PO Box 630, 0001 Pretoria

Tel: +27(0)12 304 9700; Fax: +27(0)12 3238153

e mail: normanm@ai.org.za

\begin{abstract}
Since 2000 elections in Zimbabwe have been characterised by bitter struggles, mainly between the ruling party, the Zimbabwe African National Union-Patriotic Front (ZANU-PF), and the opposition Movement for Democratic Change (MDC). In the 2000 parliamentary elections and the 2002 presidential elections these struggles became so violent that lives were lost on both sides, with the protagonists blaming each other for instigating the violence. Real and imagined violence became the language with which even the international community, especially the media, articulated the Zimbabwean crisis at the expense of other equally problematic issues such as the land question, the constitutional debate, economic and personal sanctions, drought and hunger, and poor political decisions by major players on both sides of the political divide. This paper argues that the violent character of the Zimbabwean crisis is a result of a general mood of bitterness that had been building up for decades prior to the current crisis. That mood is traceable to the brutality of the liberation struggle and the bitterness continued in the early 1980s with the Matebeleland crisis, whose violent suppression raised bitter ethnic questions. The mood continued to thicken with the militarisation of Zimbabwean politics when the war veterans entered the political fray especially after the February 2000 constitutional reform referendum. Although Zimbabwe has had a multi-party system since 1980, the real contribution of past political parties, civil society and the international community in Zimbabwe's democratic experiment has been lost in the rhetoric of violence of the last five years. The general mood of bitterness has made it impossible even for wellmeaning religious groups and concerned governments of neighbouring countries to negotiate a compromise political solution. Sections of the international media, human rights organisations and some Western diplomats, rather than helping to tone down the bitterness have increased tensions by employing the rhetoric of violence, even in the elections of March 2005, long after the conflicting parties had expressly and demonstrably abandoned violence.
\end{abstract}




\section{The ZimBABWEAN CRISIS}

Since the year 2000 Zimbabwean society has faced enormous problems of a political, economic and social nature, which collectively constitute what has been called the Zimbabwean crisis. The major issues include governance, economic meltdown, a disputed land reform process, drought and hunger, the HIV / AIDS pandemic, an exodus of professionals, and the determination of some superpowers that there be a regime change.

There are those who work tirelessly to try to resolve some of Zimbabwe's problems, but there are also those who work hard to accentuate them in order to gain political mileage. There is no general consensus as to what exactly constitutes the Zimbabwean crisis, how it started and how to resolve it. Stakeholders emphasise the explanation that furthers their own interests at any particular time. Most of those involved pull in different directions; there is no common purpose even in the international community, and no common national agenda internally. It seems that the main reason for this lack of common purpose is the acute polarisation of Zimbabwean politics which perpetuates moods of bitterness among Zimbabweans and, by extension, lack of agreement within the international community on how to handle the crisis.

\section{Political Violence During the Struggle}

A major source of bitterness among Zimbabweans is the history of violence associated with political processes. Political violence in Zimbabwe is historically rooted in the brutality of the struggle for liberation (Martin and Johnson 1981). After independence in 1980 no social or legal process was established to help people deal with the trauma suffered during the struggle, so the bitterness and mutual suspicion were perpetuated. There was no process to deal with the perpetrators and the victims of the petrol bombs that maimed hundreds of people in the townships in the 1960s and 1970s. No one dealt with the massacre of peasants in the rural areas by surrogate armies such as Pfumo Revanhu at the end of the 1970s. No one was called to account for the thousands of people who lost limbs to landmines laid by both the guerrillas and the Rhodesian Security Forces, some of which are still killing people today (Rupiya 1998).

In the optimism (Mlambo 2003, pp 57-95) brought by the new democratic dispensation nobody was brought to account for the deaths of thousands of school children who perished on their way to join liberation movements in neighbouring countries, many of them killed by security forces as they attempted to cross the border. No one was questioned about the massacres of refugees by the Smith regime at refugee camps in Mozambique and Zambia (Iliff 2004). Both Zimbabweans and the international community were in too much of a hurry to declare the success of democracy over minority white rule, and did not stop to deal effectively with the past, and that ugly past continued to affect the new Zimbabwe. There was no war 
crimes tribunal, no prosecutions for human rights violations, no truth and reconciliation process and no adequate compensation for victims on either side of the struggle.

\section{The Matebeleland crisis and other political problems in the 1980s and 1990s}

After independence, the most disturbing acts of political violence were witnessed during the Matebeleland crisis from 1981 to 1987 (Legal Resource Foundation and Catholic Commission for Justice and Peace 1997). The conflict had ethnic roots in the sense that the Zimbabwe African People's Union (ZAPU), to which the dissident elements claimed allegiance, was a party based in Matebeleland and the Midlands and dominated by Ndebele-speaking Zimbabweans. So, when government forces, who were mostly Shona-speaking, cracked down on the dissidents, they were perceived to have used excessive force. Dissident activity included the kidnapping and murder of tourists, the burning down of churches and the murder of priests, and general terrorism. And yet, the government's resolve to stop these dissident activities was internationally interpreted as an attempt to silence political opposition and to exterminate the Ndebele-speaking people. That interpretation alone had its own destabilising effects, which increased the bitterness of the Ndebele section of the population and fuelled political polarisation between the Shona and Ndebele. The situation was temporarily ameliorated by a 1987 Unity Accord between the Zimbabwe African National Union-Patriotic Front (ZANU-PF) and (PF) ZAPU, which, although it stopped the physical violence, did not remove the mutual ethnic suspicions. These suspicions still exist today and some individuals, groups and organisations are working hard to reopen those painful political wounds.

The deliberate misinterpretation of the Matabeleland crisis persists today. One observation is that it is fanned by outsiders, mainly British and some Nordic researchers. It is fed by these researchers to the international press, including the South African press. And yet, nobody has approached the people of Matebeleland to find out from them how they would like to deal with that traumatic period in their history. The people of Matebeleland are bitter, but they have not said that they will seek revenge for what happened to them during the 1980s. They want dialogue, they want someone to say sorry, they want to forgive and to move forward with their lives, but all they get is a constant reopening of their painful wounds by people who pretend to be their friends. Even the late Joshua Nkomo, who suffered so much persecution during the Matebeleland crisis, never mentioned revenge for the wrongs perpetrated on his person. He continued to preach peace, unity and reconciliation (Nkomo 1984).

On the other hand, although President Robert Mugabe and other officials have apologised to the people of Matebeleland, that is not enough. There is a need to provide a means for the victims to express themselves and to make sure there will be no repetition of such traumatic experiences. The one-sided reports of the Catholic 
Commission for Justice and Peace did not put the matter to rest either, they merely fuelled people's anger (Legal Resource Foundation and Catholic Commission for Justice and Peace 1997). One pro-Ndebele report reads as follows:

The way forward lies in the acknowledgement of the fact that a wrong was done. A sincere apology must be advanced to build a trust in the people of Matebeleland that such a breach of the people's human rights will never be repeated. Such an acknowledgement and assurance would definitely restore cordial civil-military relations in Matebeleland region.

Ndlovu-Gatsheni 2002, p 33

Also, in the 1980s the late veteran politician, the Reverend Ndabaningi Sithole, and his ZANU (Ndonga) party were associated with dissident groups operating in Chipinge South. Sithole founded the ruling party, ZANU, when he broke away from ZAPU in 1963. Yet, when he led another breakaway, from ZANU, in 1978, he was denounced as a traitor and in the 1990s his party was accused of plotting to assassinate President Mugabe. Sithole died in 2000 whilst awaiting sentence, and, even though every Zimbabwean recognises that he started the armed phase of Zimbabwe's liberation struggle, his remains were not buried at Hero's Acre, the country's ultimate symbol of honour for those who played a major role in the struggle.

In other parts of the country, political violence has been experienced during almost all election campaign periods. This violence has involved youths, mainly from ZANU (PF), clashing with other youths from opposition political parties. In some of these clashes there has been loss of life, injuries and destruction of property. In the 1990 election campaign, there were gun battles in the city of Gweru, where an opposition candidate, Patrick Kombayi, was gunned down by state security agents.

However, the most violent election period was the run up to the June 2000 parliamentary elections. The violence was linked to the land question and to the draft constitution, which was rejected in the referendum of February 2000. During the election campaign more than 30 people are reported to have died, many were injured and millions of dollars' worth of property was destroyed (Mafundikwa 2000).

\section{The Military Factor}

At one time, there was fear about what the Zimbabwe Defence Forces (ZDF) might do if there was widespread political violence caused either by opposition sponsored mass action or by war veteran sponsored civil war. ${ }^{1}$ The assumption in opposition

1 The late Masipula Sithole, a professor of Political Science at the University of Zimbabwe, analysed the military option in a series of newspaper articles in Zimbabwe. For a synthesis of his views, see Special Report No 109, the United States Institute of Peace, August 2003. See also Bond 2002. 
circles has been that the ZDF are a professional force and will support any new president who comes to power. On the other hand, because the current joint Commander of the Zimbabwe Defence Forces (CDF), General Constantine Chiwenga; the Commander of the Army, General Philip Sibanda; the Air Force Commander, Air Marshal Perence Shiri; the Commander of Prison Services, Brigadier Zimonte; and the Police Commissioner, Augustine Chihuri, are themselves liberation war veterans, the War Veterans Association have reason to believe that the security forces will be on their side in case of an uprising. This is more so in light of the declarations by the retired joint Commander of the Zimbabwe Defence Forces, General Vitalis Zvinavashe, who is also a liberation war veteran, that the defence forces will not salute anyone who seeks to compromise Zimbabwe's independence (Quintana 2002), and that the post of president of the country is a strait-jacket into which aspiring politicians have to fit.

However, in Africa, defence forces are known to harbour political ambitions of their own. There have been military coups and counter coups in many African countries, many of them triggered by situations where civilians had failed to resolve the country's problems or where political parties had become so polarised that there was no hope of a civilian negotiated political settlement. In Zimbabwe there is no need to put the defence forces to the test in the hope that they will side with one political party or another. The security forces might not side with any party and might decide to create a military government. Of course there will be protests and sanctions proposed by the international community and civil society. But some military regimes are known to have withstood such international and local pressures. Also, if such a military regime were to strike a deal with any superpower, as the Pakistani military government under General Musharaf did with the United States of America, it would put Zimbabwe's democratic experiment in cold storage. Therefore, when some people deliberately provoke the armed forces, as do some sections of the media, people have to think of the possible unwanted consequences of involving the military in politics.

Reports of alleged plots to remove President Robert Mugabe date back to 2001 (Talbot and Slaughter 2001). It appears that the main opposition party, the Movement for Democratic Change (MDC) bought into the idea during the 2002 presidential elections when its leader, Morgan Tsvangirai, called on Mugabe to go peacefully or be removed by force. This advocacy of violence culminated in the unsuccessful June 2003 mass uprising, which the MDC dubbed 'the final push' on Mugabe (Irinnews 5 June 2003). These efforts coincided with warnings from a shadowy military group based in the United Kingdom of a 'democratic revolution' (Zimbabwe Freedom Movement 13 November 2003). However, even as the British Foreign Secretary, Jack Straw, was being persecuted by the British media for shaking Mugabe's hand in public (ThisDay 29 September 2004), the British government, at least in public, repeatedly rejected calls for military intervention in Zimbabwe (Phiri 2004). 
Taking into account recent developments in the region and on the continent, it would seem that the Southern African Development Community (SADC) and the African Union (AU) are not likely to support the violent overthrow even of a controversial leader such as Zimbabwe's Robert Mugabe. While democratic forces the world over, including in Africa, are calling for an end to dictatorships, the same forces are also calling for an end to the violent overthrow of governments (Walker 2004). A military coup in Zimbabwe is likely to be extremely devastating for the SADC region.

\section{Political Parties}

As evidenced by the number of political parties that have taken part in elections since 1980, Zimbabwe is both de jure and de facto not a one-party state. It is, however, dominated by a monolithic ruling party, ZANU-PF. This party is first and foremost a liberation movement. Secondly, it is a coalition between the original ZANU-PF, led by Robert Mugabe and PF-ZAPU, led by the late Joshua Nkomo. This coalition was achieved in 1987 after a Unity Accord that ended the Matebeleland uprising described above. The Unity Accord has been hailed as the unifying force between the Shonas and the Ndebele people. However, that unity has also been criticised for disbanding PF-ZAPU, which, activists say, was swallowed up by Mugabe's ZANU-PF. As a result, there have been a number of attempts to resuscitate the old PF-ZAPU and to continue to sustain a Matebeleland based political party with the name ZAPU (Siziba 1999).

ZANU-PF half-heartedly attempted (and failed) to create a one-party state in Zimbabwe in the 1980s. It tried to practise socialism in the country, and failed at that as well. It lost the support of the urban voters in the 2000 parliamentary elections and the 2002 presidential elections, but still enjoys the support of the rural voters (News 24.com 1 April 2005). In recent by-elections, and in the March 2005 general elections, some urban constituencies began to support ZANU-PF again. But the party has been accused of using violence and intimidation tactics. Nevertheless, it continues to enjoy the support of the War Veterans Association and the Zimbabwe Defence Forces, even though these have also been accused of intimidating the population.

The MDC is the most successful opposition in Zimbabwean politics thus far (Maroleng 2004). In the 2000 parliamentary elections, the MDC won 57 seats compared with ZANU-PF's 62, putting it on what supporters called 'an almost 50/ 50 ' footing with ZANU-PF. There are not too many opposition parties in Africa, or in other parts of the world for that matter, that can claim such an achievement. The MDC, which evolved from the workers' movement led by the Zimbabwe Congress of Trade Unions (ZCTU), is supposed to be a labour-based party with most of its supporters urban based. However, the party aligned itself with white farmers, who paid for its election campaign in June 2000. It also received funding from the British Government and from international organisations. Because of this the MDC has 
been perceived as a Western puppet, a 'sell-out' party. The party did not help its image when it campaigned for economic and other sanctions against Zimbabwe, which the United States and the European Union acted upon (Mullaly 2002). These sanctions, especially on petroleum products, have hurt all Zimbabweans very badly, and the image that the MDC thrives on the suffering of Zimbabweans is difficult to erase.

The MDC has also called for and, indeed, staged violent uprisings, which they term 'mass action' and which were ruthlessly crushed by security forces. The most volatile of these violent encounters was in June 2003. It failed, but the image of a party bent on usurping power through undemocratic and violent means remains. Morgan Tsvangirai himself has said openly that Mugabe must go peacefully or he will be removed violently.

Of the smaller parties, the most prominent was the Zimbabwe Unity Movement (ZUM) of the 1990s. ${ }^{2}$ The party was led by Edgar Tekere, the former Secretary General of ZANU-PF who broke ranks with Mugabe when he observed that 'democracy in Zimbabwe was in the intensive care unit'.

ZUM seriously challenged Mugabe in the presidential election of 1990, but the party did not follow up the momentum and did not seriously campaign in subsequent elections. Tekere himself has been ill for some time and has not participated in elections since 2000. At the time of writing he was reported to have rejoined ZANU-PF and be hoping to be elected to the re-introduced Senate.

The other significant small party is the Zimbabwe Union of Democrats (ZUD), a party led by Margaret Dongo, a former ZANU-PF Member of Parliament and a former freedom fighter. In the 1990s she championed the cause of former freedom fighters who had been neglected by ZANU-PF, but when she formed ZUD she did not include other war veterans in her party's ranks. As a result, the most prominent war veterans campaigned against her. She also refused to join the MDC coalition when it was formed. Other small parties and independent players emerge at election time but these have never really challenged the major political players (The Insider June 1992; July 2003).

One problem has been the international community's assumption that the MDC will most certainly replace ZANU-PF on the Zimbabwean political scene and therefore there is very little support for other parties. However, after three successive losses in elections, in 2000, 2002 and 2005, it does not appear that the MDC will assume power any time soon. Some are already talking of the possibility of a 'third force' joining the political fray (Molokele 2005; Kwinjeh 2005). There remains, however, the possibility of a split either in ZANU-PF or in the MDC or in both, and that may drastically change the political landscape of Zimbabwe.

2 For an in-depth analysis of opposition politics in Zimbabwe, see Laakso 2003. 


\section{The NCA and the Constitutional Debate}

Zimbabwean civil society is dominated by Lovemore Madhuku, who claims that his National Constitutional Assembly (NCA) is a coalition of all civil society groups in the country (NCA website). Madhuku has received so much money from donors that he has been able to fund the activities of a number of civil organisations. The NCA itself continues to call for a new constitution before there is any political change in Zimbabwe. However, this fixation on the constitution has tended to block any other political options so that, instead of being an asset, Lovemore Madhuku's influence on Zimbabwean civil society groups is sometimes seen as an obstacle to political dialogue.

That there is need for a 'home-grown' Zimbabwean constitution is no longer an issue for debate. The fact was generally accepted in the run-up to the February 2000 Constitutional Referendum (Sachikonye 2004; BBC News 28 September 2001). Unfortunately, the issue of the new constitution was overtaken by political developments. Instead of using the opportunity, the effort and the momentum for constitutional reform, both ZANU-PF and the MDC decided to use it to gain political mileage. And here it must be admitted that both parties succeeded in gaining political strength on the basis of the negative results of the 2000 constitutional referendum. The MDC won a record number of opposition seats in Parliament in the June 2000 elections (57 MDC, 61 ZANU-PF) as a result of the momentum created by the campaign for a 'no' vote. On the other hand, ZANU-PF regained popularity in the rural constituencies by including a land clause in the proposed constitution and managed to hold on to power. But all that political mileage was gained at the expense of the constitutional reform process that all had agreed was necessary.

If the NCA had not campaigned for a 'no' vote in the constitutional referendum Mugabe would not have been eligible for re-election in the presidential elections of 2002 because the proposed constitution limited the president to two terms. It is difficult to convince people that Madhuku, a constitutional lawyer by training, did not realise that. Some have said that Madhuku wants to keep the constitutional debate alive so that he will continue to receive funding from donors. There is, therefore, a need to renew the political will for constitutional reform and this cannot be done by trying to force through an opposition sponsored document, as the NCA has been trying to do. It may be more fruitful to negotiate a new constitution in good faith than to 'demand' that government accept the NCA version of the constitution. One option is to go the South African way - achieve a political settlement first, then deal with the constitution.

\section{Religious Groups}

A number of religious groups have involved themselves in the Zimbabwean political scene. However the religious community has thus far failed to reconcile the conflicting parties. One problem is historical. During the liberation war some church 
leaders ended up on the side of the minority and racist Smith regime. Such was the fate of the Reverend Ndabaningi Sithole and Bishop Abel Muzorewa. The resentment caused by this situation is such that when religious groups such as the Catholic Commission for Justice and Peace speak about atrocities in Matebeleland, some people label them yesterday's sell-outs. And yet, there are some well-meaning religious leaders, such as the trio of Patrick Mutume, Trevor Manhanga and Sebastian Bakare, who have tried to bring the MDC and the Zimbabwean Government to dialogue. So far they have not been given the respect that their efforts deserve.

The religious atmosphere has been polluted more by people like Archbishop Pius Ncube, who speak of the government with such contempt that they leave no room for a church sponsored reconciliation process. Instead, Ncube has called for a violent uprising (Ecumenical News International March 2005), and has even prayed to God for Mugabe's death. In August 2005 the Anglican Church put its Harare Bishop, Nolbert Kunonga, on trial to answer political charges based on allegations by political activists aligned to the MDC. Fortunately the church appointed Malawian judge James Kalaile, who refused to hear the case (Zvayi 29 August 2005; BBC News 26 August 2005). There is clearly a need for the church in Zimbabwe to regain the moral high ground by advocating dialogue rather than joining one side of the political fray.

The church has made another mistake by calling for sanctions against Zimbabwe, a call led by Roman Catholic bishops (Zim Online 14 August 2004). Sanctions have reduced the availability of food, medicines and petroleum products, starving the Zimbabwean masses in the process. In Africa, hunger seldom triggers democratic uprisings, instead it often drives Africans back to the land (Lee and Colvard 2003) where they can practise survival of the fittest tactics. No wonder a recent international political survey (AfroBarometer 18 August 2004) found that 60 per cent of Zimbabweans had lost interest in political change between 1999 and 2004; they were too busy trying to survive under sanctions.

The Roman Catholic bishops certainly got the sanctions issue wrong and this disqualifies them from playing the role of peace broker. In addition, the majority of Zimbabwean Christians are not Catholics; most of them follow the emerging Pentecostal churches such as the Zimbabwe Assemblies of God Africa (ZAOGA), the Apostolic Faith Mission (AFM), Johanne Masowe, Guta ra Jehovha, Zion City Church, and the United Church of Christ (UCC). There are also many Methodist and Anglican Church followers, and none of them has called for sanctions (Media 24 Africa Service 23 January 2004).

\section{The Media as Weapons of Mass Deception}

The media are not simply observing and recording events as they unfold in Zimbabwe, they are at the centre of the Zimbabwean crisis (Media Monitoring Project 2000). The state-controlled media have done all it can to rubbish the 
opposition, the international community and all dissenting voices. On the other hand, the private media and sections of the international media, including those in South Africa, have laboured to present Mugabe as the devil incarnate. The situation is so bad that it is possible accurately to forecast the response of the main news providers to any significant event in Zimbabwe. Add to that the alleged harassment and torture of journalists by state security agents in Zimbabwe and the fabrication of stories by the private and international media, and it is clear that the media have become the psychological warfare department of the Zimbabwean crisis.

The media in Zimbabwe are polarised and divided along the same political fault lines that separate Zimbabwean society. Every media organisation in the country is either pro-Mugabe or anti-Mugabe, there is no neutral ground, despite the many pretensions by some that they are independent, and this includes regional and international media organisations, especially the South African media. Every activity in Zimbabwe is interpreted by the 'independent' media as a Mugabe activity, as if the 12 million ordinary men, women, children and the aged have no individual existence of their own.

To most Zimbabweans, however, what has been going on in the country in the past five years is not simply the manipulation of a people by an aged dictator, the Zimbabwean crisis depicts the bitter mood of a nation, a mood fuelled by acute political polarisation. All media organisations have a duty to report both sides of the political divide as accurately and as objectively as possible without becoming weapons of mass deception. And yet, in Zimbabwe, the government controlled media report only the good things about ZANU-PF, and only the ugly side of the MDC. On the other hand, the independent media present a Zimbabwe in which everything, including rivers, mountains, trees, and animals, live and die for Robert Mugabe. So much so that even the Zimbabwean side of the Victoria Falls is now being excluded from South African media presentations of regional attractions, yet it is as beautiful as it was when David Livingstone 'discovered' it 150 years ago.

There are many such beautiful places and people in Zimbabwe, which have nothing to do with Robert Mugabe, but, in the eyes of the 'independent' media they no longer exist. Even Zimbabwean art has been reduced to pro- or anti-Mugabe art. When veteran musician Thomas Mapfumo produced his politically charged song, 'Mamvemve', which sent him into exile, and Last Chiangwa (Tambaoga) responded with the equally politically charged 'Blair Toilet', the media pressurised another music guru, Oliver Mtukudzi, to declare that his song 'Kuchembera' was anti-Mugabe, even though the musician explained that the song was about any and all the aged people in Zimbabwe (Eyre 12 July 2005).

Zimbabweans, and the world at large, are not being told the true Zimbabwean story by either the local or the so-called independent international media. The true Zimbabwean story lies somewhere between the torture of Mark Chavhunduka and Ray Choto (Brinkley 2002) and Basildon Peta's fictitious murder victims (Peta 2002); between the international agencies' predictions of pending famine and mass starvation and the Zimbabwe government's forecast of future bumper harvests; 
between the 'horrors' of Operation Murambatsvina and the hopes of Operation Garikai (Tibaijuka 2005); between Mugabe begging for a loan on his knees (Degenerationx.net 24 July 2005) and the International Monetary Fund nudging the South African government to offer him an unsolicited loan (Independent online 26 August 2005).

\section{The InTERNATIONAL COMMUNITY}

The Zimbabwean crisis has affected and been influenced by a number of regional and international countries and organisations, to such an extent that it has ceased to be a domestic issue and become an international and multilateral one. For example, one of the reasons advanced by the MDC for not accepting the results of the 2000 parliamentary elections and the 2002 presidential elections was that the international community did not pronounce them free and fair. Recently, Zimbabwean sport, especially cricket, has been under pressure (Cricinfo 21 August 2005) mainly because of the campaign to have Zimbabwe banned from playing Test cricket, a campaign championed by Australia, New Zealand and the United Kingdom. The cricket crisis has been aggravated by allegations of racism, leading to 15 white players holding the Zimbabwe Cricket Union to ransom for a whole year. Even when the International Cricket Council ruled that Zimbabwe would maintain its Test cricket status, the international media and regular cricket advertisers ignored the triangular series played in Zimbabwe in August 2005 between New Zealand, India and Zimbabwe (Pak Tribune 29 August 2005).

The thorny issue of Zimbabwe's withdrawal from the Commonwealth (The Age 14 December 2003; BBC News 8 December 2003) is already an international issue which threatened to split the Commonwealth on racial lines. The major cause of the Zimbabwean crisis, land reform, already involves the British government, the United Nations Development Programme (UNDP), the Commonwealth and the African Union (AU). The economic situation has been aggravated by economic sanctions imposed by the European Union (EU), the USA, the rest of the donor community, the IMF and the World Bank. Therefore, some member of the international community, instead of merely being observers, are actual players who have even initiated moves that have impacted on the Zimbabwean situation, in most cases negatively.

For example, some Nordic countries, Denmark, for instance, have closed their embassies in Zimbabwe and have stopped economic cooperation and aid even to non-governmental organisations. Even international gay organisations took an antiMugabe stance, with Peter Tatchell, a British national, on the front line (BBC News 6 March 2001; Exodus October 1999; BBC News 16 November 1999).

The British government has been at the centre of the Zimbabwean land question for more than 100 years, yet the former British ambassador to Zimbabwe (Sir Brian Donnelly) was the most outspoken member of the diplomatic community, especially on the subject of Zimbabwe's land reform. His statements greatly shaped British, 
EU, Australian and American policy on Zimbabwe. He was obviously not a neutral player, yet his voice was influential not only to the British audience, but to most of the Western world. It is also not clear at a time when Tony Blair and his Commission for Africa and the G8 are campaigning for debt cancellation for poor African countries, why the IMF is demanding that Zimbabwe pays its debt of close to US\$300-million, knowing very well that such payment, like the Shakespearian Shylock's demand for a 'pound of flesh', would most certainly bleed Zimbabwe's economy to death?

\section{WrONGLY FOCUSED INITIATIVES}

Thus far conflict transformation in Zimbabwe has focused on talks between ZANU$\mathrm{PF}$ and the MDC but apart from the informal 'talks about talks' this inter-party dialogue has not yielded any fruits (Bruce and Katzenellenbogen 25 May 2004). It is frequently suggested that the talks should be between Robert Mugabe and Morgan Tsvangirai and that there has been no meaningful dialogue because the two refuse to find any common ground on which to initiate such talks. In fact, if the Zimbabwean political impasse is to be broken, there is a need to broaden the dialogue beyond Mugabe and Tsvangirai; beyond ZANU-PF and the MDC; and to hold a national dialogue that includes all other stakeholders.

A recent international survey of political opinion in Zimbabwe concluded that too much focus on Mugabe has done more harm than good to the forces of change (Chikwanha et al 2004). The Zimbabwean crisis emanates from the bitter mood of Zimbabwean society, and to resolve it there is need for a national dialogue, not just talks between Mugabe and Tsvangirai or between ZANU-PF and the MDC. There is also a need to widen the discourse beyond mere regime change to include issues such as economic recovery, post-conflict reconstruction, south-south cooperation and regional security, issues which the forces of change have been ignoring with reference to Zimbabwe, and which Mugabe has capitalised on.

It does not help Zimbabwe for the forces of change to appear to be led by Western countries such as Britain and the United States at a time when Westernsponsored mercenaries are haunting the continent (Sengupta 2004; Dovkants 2004) and when Mugabe is receiving standing ovations at almost every African gathering. There is clearly a need for the forces of change to engage the African psyche and to understand why African beacons of hope such as president Thabo Mbeki insist on quiet diplomacy towards Zimbabwe (Peta and Quintal 2004) and why a reputable British magazine voted Mugabe 'the third greatest African of all time' after Nelson Mandela and Kwame Nkrumah (New African August/September 2004).

\section{The 2000 Parliamentary ANd 2002 PResidential Elections ${ }^{3}$}

The biggest problem with the general elections of June 2000 and the presidential election of 2002 was political violence. Most of that violence was a spill over from 
the violent land occupations that started after the rejection of a proposed new constitution in February 2000. The war veterans were on the warpath, and so were the government sponsored youth brigades, the so-called Border Gezi or Green Bombers. But even these did not have a monopoly on violence - white farmers were violently resisting land invasions. For example, in Odzi, near Mutare, a white farmer drove over a black settler, killing him, in full view of other black settlers. He was arrested and sent to prison. The MDC from its youth wing to its members of Parliament right up to its leader, Morgan Tsvangirai himself, was also on the warpath. One MDC member of Parliament, Learnmore Jongwe, was so violent that he stabbed his own wife 28 times with a kitchen knife during that period. The wife died on her way to hospital and Jongwe committed suicide while awaiting trial. Later, another MDC member of Parliament, Roy Bennet, violently assaulted two Cabinet ministers during a bitter debate in Parliament and was imprisoned for one year.

Between 2000 and 2003, the MDC as a party thought they could remove ZANUPF from power by force. After losing the parliamentary elections in June 2000, Morgan Tsvangirai made a public speech to the effect that if Mugabe did not step down peacefully, the MDC would remove him violently. This call was strengthened by European and American references to a Milosevich-style mass action to remove Mugabe. Indeed, the MDC mobilised several attempted civil disobedience mass protests in major cities throughout the country, but they were all brutally thwarted by the Zimbabwean security forces. The most publicised of these MDC mass action initiatives was held in June 2003 and was dubbed, 'the final push'. In the meantime, it was alleged that Tsvangirai was negotiating with a Canadian based former Israeli secret agent to assassinate Robert Mugabe. The plot fell apart when the agent, Ari Ben Menashe, became a double agent and worked with ZANU-PF to smear Tsvangirai. Tsvangirai was charged with treason and acquitted. This history of violent politics was the reason why some observers declared that the parliamentary elections of June 2000 and the presidential election of February 2002 were not free and fair.

During the run-up to the 2002 presidential election Zimbabwean politics was so polarised that whatever the result of that election it was unlikely to bring durable peace to the country. Some, including many ZANU-PF activists and some sections of the Zimbabwe Liberation War Veterans Association, threatened civil war if Tsvangirai won the presidential election. Some senior government officials also said they would rather go back to the bush to wage another guerrilla war if Morgan Tsvangirai 'sold Zimbabwe back to the British' and returned land to white farmers. These were not just noises to try to frighten the opposition, they were real threats.

A similar situation arose in Mozambique when RENAMO took up arms to fight the Mozambican Government, sparking two decades of civil war. That war

3 For an in-depth analysis of the 2002 presidential elections, see Amani Trust, Network of Independent Monitors and Physicians for Human Rights 15 March 2002. 
achieved nothing and the two parties finally agreed to political dialogue and political compromise (Armon, Hendrickson and Vines 1998). Unfortunately, the Mozambican political compromise was achieved after the death of millions of Mozambicans and the total destruction of the country's infrastructure.

\section{The 2005 Elections}

The most positive aspect of Zimbabwe's March 2005 parliamentary elections compared to its two predecessors was the fact that there was no political violence at all. However, human rights pretenders in Zimbabwe, South Africa and some Western countries, led by Amnesty International, decided to ignore that fact and to fan the discourse of violence in the country (Amnesty International 2005). After the elections, instead of encouraging a positive way forward, the anti-Mugabe group shifted their focus to manufactured 'evidence' of vote rigging, trying to incite violent protest against the results, even when the leadership of the MDC declined to challenge the results (Timberg 2005). This call for a violent uprising led some MDC youths who were not in touch with reality to start violent protests in Harare the day after the announcement of the results. Fortunately they were quickly neutralised by the police (The Herald 4 April 2005).

Those who were in Zimbabwe on the day of the elections and who watched the counting of the votes and the public announcement of the results in the three days that followed described the elections as peaceful, credible and reflecting the will of the Zimbabwean people. This view was held by, among others, observers from 14 SADC countries, from the South African Parliament and from the African Union. On the issue of equal access to the public broadcaster, the Zimbabwean government opened up the airwaves for campaigns by all political parties and even dismissed the much hated Jonathan Moyo from the Ministry of Information and from ZANU-PF (Nyago 2005). Of course, there are those who ague against the SADC pronouncement of a free and fair poll and maintain that the SADC guidelines were not met. This is clearly a case of outsiders who mourn louder than the bereaved.

One contentious issue was that Zimbabwe's voters' roll contained the names of dead people, the so-called 'ghost voters'. The voters' roll was compiled in 2002, based on the national census of that year, and was subsequently digitalised and updated up to 28 February 2005 (FreeZim Support Group 27 February 2005). Obviously, people continued to die (as they do in great numbers in these days of HIV and AIDS) after that date and needed to be removed from the voters' roll. On the other hand, some people turned 18, the legal age of adulthood in Zimbabwe, and became eligible to vote during that period. So any registered voter who had died and whose death was not reported to the election authorities will continue to be on the voters' roll until the next census, and anybody who turned 18 during that period and who did not register to vote will not be on the roll until the next census. But, as South Africa's Minister of Labour, who was tackled on the issue by journalists, explained, dead people do not vote. In any case, it is not only people who would 
have voted for ZANU-PF who died, some potential MDC voters also died during that period and could be described as 'ghost voters'.

Another hot issue was that of the exclusion of expatriate voters. It was alleged that the exclusion of expatriate voters meant that close to 3 million voters in the diaspora were disenfranchised. The explanation from Zimbabwe's Independent Electoral Commission was that the Zimbabwean system is constituency based, and it would be difficult to distribute millions of votes cast outside the country to their proper constituencies. Also, because of the travel restrictions imposed on some candidates by Western governments, it would have been impossible for candidates to campaign in the diaspora. Those who were able to return home to vote were encouraged to do so and a good number of Zimbabweans, especially from the SADC region, did so. The South African television channel SABC 3 followed some of these expatriates from Johannesburg to rural areas in Zimbabwe and confirmed that they were, indeed, free to vote in their constituencies (Special Assignment 19 April 2005).

However, a number of Zimbabweans in the diaspora could neither go home to vote nor would they have been able to vote even if the ballot had been brought to them. This is because many of them have applied for asylum and some already have refugee status and new identity documents. Some have forged documents and others have voluntarily changed their citizenship. In the United Kingdom, for example, many Zimbabweans are on the run from immigration authorities ever since the British government started deporting Zimbabwean asylum seekers whose applications had failed. Only the foolish would have exposed themselves to deportation by going to a Zimbabwean polling station anywhere in the UK. This was demonstrated by the fact that despite the noise about a mock expatriate vote in South Africa and the UK, the total number of those who cast the mock vote in both countries did not even reach 10 000. What happened to the 3 million potential voters who were constantly being mentioned by the media? And what is there to say that all Zimbabweans in the diaspora would have voted for the MDC?

Some international and regional groups, such as Amnesty International, International Crisis Group, and the Zimbabwe Solidarity and Consultative Forum, among others, which have been campaigning for the MDC (Froese 2005) have tried to evoke their misconceptions of human rights violations in Zimbabwe as a reason to discredit the March 2005 elections. Such groups, however, ignore the fact that the right to choose government representatives is a human right. Article 21 of the United Nations Universal Declaration of Human Rights reads as follows:

(1) Everyone has the right to take part in the government of his country, directly or through freely chosen representatives.

(2) Everyone has the right of equal access to the public service in his country.

(3) The will of the people shall be the basis of the authority of government; this shall be expressed in periodic and genuine elections 
which shall be by universal and equal suffrage and shall be held by secret vote or by equivalent free voting procedures.

The above is corroborated by the African Charter on Human and People's Rights, which, in Article 13, repeats the UN declaration and adds that free participation in the government of one's country shall take place 'in accordance with the provisions of the law' of that country. There is no human rights declaration anywhere in the world that says that the freeness and fairness of elections shall be determined by human rights activists or by the European Union or by the United States of America.

For the record, the following facts about Zimbabwe's March 2005 elections must be restated:

- Voting was by means of a secret ballot and was open to all adults who had attained the age of 18 years and above, and who had registered to vote by 28 February 2005.

- The elections were run by an Independent Electoral Commission and followed the SADC guidelines on democratic elections.

- Ballot boxes were transparent and at every polling station the boxes were inspected by polling agents appointed by the MDC, ZANU-PF and independent candidates where applicable.

- Voting took place on one day.

- Counting was done at each polling station in the presence of polling agents from all contesting parties.

- The results in each constituency were announced in public, in full view of the media and local and regional observers, and in the presence of candidates or representatives of all parties contesting each constituency.

- The MDC and ZANU-PF had polling agents at all polling stations and their names were advertised in all the national newspapers days before the election date. The polling agents inspected all boxes to make sure there were no papers stuffed in them before polling started.

But the bitterness of some human rights pretenders such as those in the South African chapter of Amnesty International is not really about whether the Zimbabwean elections were free and fair but about the fact that, according to them, the MDC should have won the elections. In fact, the MDC did win the majority of the urban constituencies, which is what all serious political analysts and opinion polls had predicted. So, if Morgan Tsvangirai had contested any constituency in Harare or Bulawayo he would have won and would be a member of Parliament. Just why he did not contest in the urban areas and lead his party in Parliament has baffled a number of analysts. It also appears that the fact that Tsvangirai had remained outside Parliament for the previous five years and will do so again for the next five adds to the bitterness of the MDC and its leader. 
On the regional scene, the Zimbabwean elections generated more excitement in South Africa than in Zimbabwe itself. Yet internationally, the majority of commentators and opinion makers agreed long before the election date, that the ruling ZANU-PF would win (See, for example, Nolan 2005). The only debate was whether ZANU-PF would win freely and fairly or whether it would win by intimidation and violence. As observed earlier, there was no violence at all before or during the March 2005 elections. Although few political analysts entertained the opinion that the MDC would unseat ZANU-PF, when the results came out, giving ZANU-PF 78 seats against 41 for the MDC and one for independent candidate Jonathan Moyo, the usual suspects still cried foul.

Between the beginning of 2004 and the end of March 2005 there was a period of political non-violence in Zimbabwe. Both the MDC and ZANU-PF sent constant messages to their supporters that the leadership would not tolerate any form of violence. The government disbanded the feared youth brigades and the police adopted a zero tolerance approach to political violence. So that in the run up to the elections of 31 March 2005 it was common to see MDC supporters holding a political rally right next to a ZANU-PF political gathering, with no form of confrontation whatsoever and such images were constantly aired on national television. After the elections and when the results were announced, again national television showed MDC and ZANU-PF supporters celebrating together and sharing traditional beer mugs. Why then did human rights pretenders ignore such peaceful developments (see, for example, Zavis 2005).

To genuine peace lovers, the 2005 elections should have been declared a dream come true. Religious organisations which had mobilised numerous prayers for peace in Zimbabwe were jubilant. With the exception of the Catholic Archbishop of Bulawayo, Pius Ncube, who prayed for Mugabe to die, most Zimbabwean church leaders commended the Zimbabwean population for a peaceful political process (Christian Post 2 March 2005). Even the traditionally anti-Mugabe Catholic Commission for Justice and Peace (CCJP) hailed the improved political climate (The Herald 2 April 2005). Tsvangirai himself expressed satisfaction at the reduced level of political violence. Yet the miracle was missed by the loudest international democracy and human rights watchers. Instead of campaigning for peace, Amnesty International and other suspect organisations fomented regional unrest by organising endless protests throughout South Africa, with the politically ambitious Congress of South African Trade Unions (COSATU) (newzimbabwe.com 4 November 2004; Amnesty International South Africa 12 and 13 March 2005).

United Nations Secretary General Kofi Anan welcomed Zimbabwe's peaceful elections (UN News Service 4 April 2005) yet the American Secretary of State, Condoleezza Rice, labelled Zimbabwe an outpost of tyranny (19 January 2005) while the British press demonised Jack Straw and Prince Charles for shaking hands with Robert Mugabe (Milno 2005). But the same countries and many democracy and human rights activists hailed elections in Afghanistan and in Iraq that took place under military occupation with bombs exploding everywhere (literally) and dozens 
of people being killed on the polling days. In Iraq, international democracy activists argued, correctly, that, even though the elections were not perfect, they were an important step towards the democratisation of Iraq. The same argument should have been applied to Zimbabwe.

\section{- REFERENCES -}

\section{Print Publications}

Amani Trust Network of Independent Monitors and Physicians for Human Rights. 2002. 'Analysis of Zimbabwe Presidential Election March $9^{\text {th }}$ and $10^{\text {th }} 2002^{\prime}$. Report. Harare and Denmark 15 March.

Armon, J, Dylan Hendrickson and Alex Vines.1998. The Mozambican Peace Process in Perspective. ACCORD International Review of Peace Initiatives, Issue 3. London: Conciliation Resources and Maputo: Arquivo Historico.

BBC News. 1999. 'Tatchell charged over Mugabe protest', 16 December. 2001. 'Tatchell defends Mugabe arrest', 6 March.

Bruce, Peter and Jonathan Katzenellenbogen. 2004. 'Behind the Smokescreen of Talks'. Business Day, 25 May.

Chambers, Madeline. 2004. 'TV cameras capture Straw's gaffe with Mugabe'. Johannesburg: ThisDay, 29 September.

Chikwanha, Annie et al. 2004. 'The Power of Propaganda: Public Opinion in Zimbabwe'. Cape Town: AfroBarometer, Working Paper No 42, in collaboration with Idasa.

Exodus. 1999. 'Zimbabwe's President Mugabe Detained on Charges of Torture by Gay Rights Protesters', 30 October.

Herald, The. 2005. 'CCJP hails improved political climate'. Harare, 2 April.

- 2005. 'MDC unleashes violence'. Harare, 4 April.

Iliff, A R. 2004. 'Arresting Impunity: Towards a Transitional Justice Paradigm for Zimbabwe'. Unpublished, BA Hons Dissertation, Harvard.

Lee, Margaret C and Karen Colvard (eds). 2003. Unfinished Business: The Land Crisis in Southern Africa. Pretoria: Africa Institute of South Africa.

Legal Resource Foundation and Catholic Commission for Justice and Peace. 1997. Breaking the Silence, Building True Peace: A Report of the Disturbances in Matabeleland and the Midlands 1980-1989. Zimbabwe: Catholic Commission for Justice and Peace.

Maroleng, C. 2004. Zimbabwe's Movement for Democratic Change: Briefing Notes. Pretoria: Situation Report, Institute for Security Studies.

Martin, David and Phyllis Johnson. 1981. The Struggle for Zimbabwe: The Chimurenga War. London: Faber and Faber.

Media Monitoring Project (Zimbabwe). 2000. Election 2000: The Media War. Harare. Mlambo, Alois. 2003. 'The Ambiguities of Independence, Zimbabwe 1980-1990'. In Margaret C Lee and Karen Colvard (eds). Unfinished Business: The Land Crisis in Southern Africa. Pretoria: Africa Institute of South Africa. 
Mullaly L. 2002. 'The EU and Zimbabwe: Too Little Too Late?' European Security Review. Brussels: International Security Information Service (ISIS).

Ndlovu-Gatsheni, S J. 2002. 'The Post-Colonial State and Matebeleland: Regional Perceptions of Civil-Military Relations, 1980-2002'. In Rocky Williams, Gavin Cawthra and Diane Abrahams (eds). Ourselves to Know: Civil Military Relations and Defence Transformation in Southern Africa. Pretoria: Institute for Security Studies.

New African 432. London, August/September 2004.

News 24.com. 2005. 'Zimbabwe: Rural votes will clinch it'. Harare, 1 April.

Nkomo, Joshua Mqabuko. 1984. The Story of My Life. London: Methuen. Reprinted 2001 Harare: SAPES Books.

Pak Tribune. 2005. 'Regular cricket advertisers ignore Zimbabwe series'. New Delhi, 29 August.

Peta, Basildon and Angela Quintal. 2004. 'No alternative to quiet diplomacy in Zim'. Pretoria News, 25 May.

Rupiya, M. 1998. Landmines in Zimbabwe: A Deadly Legacy. Harare: SAPES Books. SABC 3. 2005. Special Assignment, aired on Wednesday 19 April at 21:30 hours. Sachikonye, L. 2004. 'Constitutionalism, the Electoral System and Challenges for Governance and Stability in Zimbabwe'. African Journal on Conflict Resolution 4 (2). Durban: The African Centre for the Constructive Resolution of Disputes (ACCORD).

Sithole, Masipula. 2003. Zimbabwe and the Prospects for Nonviolent Political Change. Special Report No 109, the United States Institute of Peace, August. Washington, DC.

Siziba, N. 1999. 'Succeeding Father Zimbabwe'. The Zimbabwe Mirror, 16 July.

Tibaijuka, A K. 2005. Report of the Fact-Finding Mission to Zimbabwe to assess the Scope and Impact of Operation Murambatsvina by the UN Special Envoy on Human Settlements. Harare, 18 July.

UN Office for the Coordination of Humanitarian Affairs. 2003. 'Zimbabwe: Focus on the MDC's "final push"'. Johannesburg: Irinnews, 5 June.

.2002. 'Zimbabwe: IRIN Chronology of EU Sanctions'. Johannesburg, 20 February.

Walker, Kenneth. 2004. 'African states no longer the putsch-over they once were'. Sunday Times, 14 March.

\section{Online publications}

AfroBarometer Media Briefing, 18 August 2004 www.afrobarometer.org Age, The. 2003. 'Zimbabwe formalizes Commonwealth withdrawal', 14 December http: / / www.theage.com.au/articles / 2003/12/13/1071125714239/html

Amnesty International. 2005. 'An assessment of human rights violations in the runup to the March 2005 parliamentary elections'. Report posted on the MDC website under the title VIOLENCE http://www.mdczimbabwe.org/ Violence/ amnestyreport2005.htm 
Amnesty International South Africa. 2005. 'Zimbabwe Solidarity Rally, 12 and 13 March' http: / / www.amnesty.org.za/ solidarity.htm

BBC News. 2005. 'Zimbabwe Bishop trial collapses', 26 August http: / / news.bbc.co.uk/ 2/hi/africa/4187560.stm

Bond, Patrick. 2002. 'Zimbabwe: On the brink of change, or of a coup?' Znet Commentary, 30 January 2002. Available at http: / / www.zmag.org/ sustainers / content/2002-01/30bond.cfm

Brinkley, J. 2002. Zimbabwe and the Politics of Torture. Special Report No 92, United States Institute of Peace, Washington, DC http:/ / www.usip.org/pubs / specialreports / sr92.html

Christian Post, The. 2005. 'Zimbabwe Church leaders Applaud Peaceful Atmosphere', 2 March http: / / www.christianpost.com/article/africa/351/section/ zimbabwe Cricinfo. 2005. 'British Ministers Call on ICC to Ban Zimbabwe', 21 August

http: / / contest-usa.cricinfo.com/england/content/ story /

216683.html?wrapperty=print

De-generationx.net. 2005. 'Mugabe begs China', 24 July http: / / www.degenerationx.net/node/338

Democratic Constitution for Zimbabwe, BBC News, 28 September 2001 http:/ / news.bbc.co.uk/1/hi/world/ africa/1569284.stm

Dovkants, Keith. 2004. 'New details of Thatcher coup plot'. This is London, 26

August http: / www.thisislondon.co.uk/til/jsp/modules / Article/

print.jsp?itemID $=12810227$

Ecumenical News International. 2005. 'Zimbabwe Catholic Archbishop enrages ruling party with uprising call'. Geneva, 28 March http://www.eni.ch/articles/ display.shtml?05-0208

Eyre, Banning. 2005. Two Different Musical Takes on Politics in Zimbabwe. NPR World Music, 12 July http: / / www.npr.org/templates/story / story.php?storyId=4750457

FreeZim Support Group. 2005. 'Voters Roll Audit: Preliminary roll - 2005 General Elections', 27 February. http://www.kubatana.net/html/archive/elec/ 0503222freezim.asp?sector=ELEC

Froese, Udo W. 2005. 'Tightening the Noose Around Harare's Neck?'. New Era,

Windhoek, 11 February http: / / allafrica.com/stories/printable/ 200502110653.html

Independent online. 2005. 'SA offered Zimbabwe a loan, Zim minister says', 26 August.

Insider, The. 1992. 'New parties spring up but pose no threat to ZANU-PF'. June. Kagoro, Brian. 2003. 'The Opposition and Civil Society'. The Insider, July http:/ / www.insiderzim.com/jun92lead.html and http:/ / www.insiderzim.com/ jul03guest1.html

Kwinjeh, Grace. 2005. 'Third Force or counter revolutionary claptrap?' newzimbabwe.com, 4 April http: / / www.newzimbabwe.com/pages / thirdforce4.12475.html 
Laakso, Lisa. 2003. 'Opposition Politics in Independent Zimbabwe'. African Studies Quarterly, The online Journal for African Studies http: / / www.africa.ufl.edu/asq/ $\mathrm{v} 7 / \mathrm{vi} 2 \mathrm{a} 6 . \mathrm{htm}$

Mafundikwa, E. 2000. 'Churches Call for Inquiry into Zimbabwe's Pre-election

Violence'. Christianity Today magazine. Available at http: / /

www.christianitytoday.com/ct/2000/128/55.0.html

Media 24 Africa Service. 2004. 'Zim churches in "conspiracy"', 23 January

http: / / www.news24.com/News24 / Africa / Features /0,2-11-37_1473029,00.html

Milno, Cahal. 2005. 'Charles in new PR disaster for shaking hands with Mugabe'.

The New Zealand Herald, 9 April http: / / www.nzherald.co.nz /

index.cfm?c_id=2\&ObjectID $=10119570$

Molokele, Daniel. 2005. 'Zimbabwe's new Third Force'. Mail E Guardian online, 11 March.

NCA: What is the NCA? Description on the NCA website http: / / www.nca.org.zw newzimbabwe.com. 2004. 'Amnesty leads Zimbabwe border blockade', 4 November http: / / www.newzimbabwe.com/pages / protest15.11855.html

Nolan, Stephanie. 2005. 'Holding their breath for the inevitable'. The Globe and Mail,

12 March http: / / www.theglobeandmail.com/servlet/story/

LAC.20050312.ZIMBABWE12

Nyago, Kintu. 2005. 'Mugabe Wise to Drop Prof. Moyo'. The Monitor (Kampala), 14 January http: / / allafrica.com/stories / printable/200501130733.html

Peta, Basildon. 2002. 'Mother Beheaded in Front of Daughters'. London: Independent, 24 April http:/ / www.africancrisis.org/ZZZ/ZZZ_0547.ASP. The newspaper later retracted the story as having been false.

Phiri, Gift. 2004. 'UK rules out military intervention in Zim'. The Zimbabwe Independent 9 July http: / / www.theindependent.co.zw/ news / 2004/July / Friday9/983.html Quintana, M. 2002. 'How Loyal is Zimbabwe's Army?'. BBC News, 10 January http: / / news.bbc.co.uk/1/world/africa/1754063.stm

Reynolds, Paul. 2003. 'Zimbabwe: Test for Commonwealth'. BBC News, 8 December http:/ / news.bbc.co.uk/go/pr/fr/-/1/hi/world/africa/3300117.stm

'Rice's new axis: 'outposts of tyranny', 19 January 2005 http:/ / www.smh.com.au/ news / Global-Terrorism/Outposts-the-new-axis-Rice-fingers-US

Sengupta, Kim. 2004. A very British coup? Top Tories dragged into brewing heir's African adventure. The Independent, 19 July http:/ / news.independent.co.uk/ world / africa / story.jsp?story $=524376$

Talbot, Chris and Barbara Slaughter. 2001. 'Alleged coup plot in Zimbabwe'. World Socialist Website, 1 June http: / / www.wsws.org/articles/2001/jun2001 / zimj01_prn.shtml; http: / / www.irinnews.org / print.asp?ReportID=34558

Timberg, Craig. 2005. 'Opposition leader won't fight results of Zimbabwe election'. The Washington Post 4 April http: / / seattletimes.nwsource.com/cgi-bin

UN News Service. 2005. 'Noting peaceful Zimbabwe poll, Anan calls for constructive dialogue by all parties', 4 April http://www.un.org/apps/news/ printnews.asp?nid=13863 
Zavis, Alexandra. 2005. 'Violence Skews Zimbabwe Election'. ABC News, 21 March http: / / absnews.go.com/International/print?id=599644

Zimbabwe Freedom Movement. 2003. 'Mugabe warned: Step down or be removed by force'. ZFM website, 13 November http://www.petertatchell.net/ international/zfmlaunch.htm

Zim Online 2004. 'Catholic Bishops: "Impose smart sanctions against Zimbabwe's rulers"', 14 August http: / / www.zwnews.com/issuefull.cfm?ArticleID=9903

Zvayi, C. 2005. 'Kunonga: On Trial for His Country'. Harare: The Herald 29 August http: / / allafrica.com/stories / printable/200508290955.html 